\title{
Faith-Based Organizations-State Relation and the Democratization Process in Kenya
}

\author{
Solomon Owuoche \\ Department of Political Science and Public Administration, University of Nairobi, Nairobi, Kenya \\ Email: solomon.owuoche@uonbi.ac.ke
}

Received 4 March 2015; accepted 22 March 2015; published 27 March 2015

Copyright (C) 2015 by author and OALib.

This work is licensed under the Creative Commons Attribution International License (CC BY). http://creativecommons.org/licenses/by/4.0/

(c) (i) Open Access

\section{Abstract}

This article examines how Faith-Based Organizations (FBOs)-state relation influences the democratization process in Kenya. Ideally, the state should be in the forefront in nurturing the democratization process. However, evidence suggests that the Kenyan state has for a long time appeared as an unwilling participant in the democratization process. Instead, the Kenyan state has refused to let go of the old system of governance associated with restricted political freedoms, ethnic discrimination, human rights abuse and grand official corruption, among others. It is the failure by the state to lead from the front that has created an enabling environment for the participation of FBOs (an element of civil society) in the democratization process. Ideally FBOs step in to act as a check and balance against the excesses of the state. It is argued that FBOs-state relation can be explained in terms of either cooperation or hostility. A major argument is that the contribution of FBOs to the democratization process is higher when the relationship between FBOs and the state is hostile. FBOs' contribution to the democratization process is the lowest when the relationship between FBOs and the state is cordial (cooperation).

\section{Keywords}

Faith Based Organizations, Democratization Process, Civil Society Organizations

Subject Areas: Politics, Sociology

"Activists and government cannot be expected to be comfortable bedfellows when the traditional role of lobby groups is to keep the government in check."

—Karuti Kanyinga, Columnist, Sunday Nation, $1^{\text {st }}$ March 2015: 10 [1]

\section{Preamble}

Faith-Based Organizations (FBOs) are a component of Civil Society Organizations (CSOs). The article adopts 
Fredrick Hegel's (1988) [2] approach in understanding civil society as the lacuna that exists between the state and the family. FBOs are therefore a part of and an important element of Civil Society Organizations (Owuoche, 2011: 65) [3]. From this it is clear that FBOs are political in nature and represent a legitimate arena of defense against the state, and must therefore be conceptualized as existing against the state as noted by Keane (1988) [4]. It is the independence from the state that makes FBOs active participants in the democratization process. The riding argument therefore is that FBOs apply pressure on the state to adhere to the democratic procedures and principles in the practice of governance (Owuoche, 2010) [5]. This article adopts Diamonds (1999) [6] definition of FBOs (he refers to them as religious organizations) as guided by the divine and is primarily created to meet the spiritual needs of the people so that their participation in democracy in general means an extension into the realm of CSOs. In other words, FBOs exist to advance the interest of the mainstream religion, but take forms that are different from mainstream religion due to their active participation in politics. It is in line with this that the article looks at FBOs-state relation, explained in terms of cordial and hostile, and how this relation influences the democratization process in Kenya.

\section{The Link between Politics and Religion}

The fusion of politics and religion creates an environment that is not suitable for good governance and democracy (Filali-Ansary, 2003) [7]. Instead, a cordial relationship between FBOs and State is usually for the fulfillment of each other's interest that does not necessarily aim at the promotion and protection of democratic principles in the governance of society (Huntington, 1984; Throup, 1995) [8] [9]. It is in line with this that the article argues that the in-cooperation of FBOs by the state leads to loss of FBOs' political activism. It weakens it as legitimate arena of defense against the state. It is only when FBOs exist as a "contradictory construct" to the state that one can be able to explain their contribution to democratic struggle (Mamdani, 1995: 604) [10].

During the times of Machiavelli (1952) [11] in the $15^{\text {th }}$ Century, the Church was closely associated with the state in the task of governing. The Pope had a dual role as the spiritual head of the church and as the temporal ruler of the states (Sibley, 1996: 294) [12]. It is this fusion of politics and religion that Machiavelli saw as a major factor contributing to the decay and disintegration of Italy due to the absence of an effective system of checks and balances. Machiavelli points out that the rulers (Clergy) were not restrained by moral scruples and that "all had bastard children, ... [who] sought to advance their families as rapidly as possible, whether in terms of money or of political power" (Sibley, 1996: 295). Huntington (1984), Throup (1995) and Filali-Ansary (2003) echo Machiavelli's sentiments. Huntington (1984) argues that there is a strong correlation between Protestantism and democracy. He notes that Protestantism has promoted a culture of rebellion towards established authority leading to significant gains on the democratic front. This is unlike in countries that have a Roman Catholic leaning that show a cordial relation between the state and Church with the consequence being an ambivalent attitude towards democratization project. The state and Church may end up serving their own selfish interests that is sometimes at variance with the interests of the general public good. Throup (1995) also argues along similar lines to that of Huntington. According to Filali-Ansary (2003), those countries that are predominantly Muslim are highly unlikely to adhere to democratic procedures and principles in the governance of society. This is due to the fused spheres of religion and state that do not allow for an effective system of checks and balances against the excesses of the state.

\section{FBOs-State Relation in Kenya}

\subsection{Colonial Period and President Jomo Kenyatta Eras 1884-1978: Cordial Relations}

FBO-state relation can be explained in terms of either cordial or hostile relations. The Colonial period (1884-1963) and President Jomo Kenyatta Era (1963-1978) had a cordial relation between FBOs and state. The President Moi Era (1978-2002) shows a hostile relation between FBOs and state due to open criticism of state and bad governance. This open criticism by FBOs elicited direct criticism by government. More specifically the Colonial Era and the immediate post-independence period witnessed a cordial relationship between FBOs and the state in Kenya. The FBOs were to a large extent mainly concerned with "missionary and evangelizing missions" so that at no time did the objective(s) of the FBOs' conflict with that of the state. On the one hand the state dealt with temporal matters while the FBOs dealt with religious matters. It was a case of "render unto Caesar the things that are Caesar's" (Throup, 1995: 143) and to God what belongs to God. As argued by Throup (1995), it is this "toge- 
therness" that made the FBOs to be extra cautious and reluctant to engage in politics (considered the preserve of the state) even with the dawn of independence.

\subsection{The President Moi Era (1978-2002): Hostile Relations}

The Moi Era clearly shows that conflict between FBOs and state led to enhancement of democratic procedures and principles in the governance of society. One can argue that the democratization process is largely dependent on the struggle between two polarities: the FBOs on the one hand and the state on the other. Out of the confrontation between FBOs and the state, the state would be compelled to embed democratic principles in the practice of governance. These principles include enhanced political freedoms; rule of law and the state being accountable to the citizenry. FBOs have therefore come in as an agent of democratic change and this has put them in a collision path with the state.

With the reintroduction of multiparty politics in Kenya in 1991 following the repeal of Section 2(A) that had made Kenya a dejure one-party system, the relationship between FBOs and the state was that of suspicion and open antagonism. The government was usually sensitive, and hostile to criticism. President Daniel Arap Moi warned civil servants to avoid dealing with FBOs in any way. FBOs' open criticism of the state and bad governance elicited the President's criticism. The President cast FBOs as subversive implying they were an anti-government organizations involved in activities not legal. As a consequence civil servants began to pay more attention to the work of FBOs at the local level with a view of harassing the FBOs and their staff. What the government detested most - and served to cause more worry on the part of government officials—was the FBOs activities in peace building in areas that had been most affected by the politically instigated ethnic clashes following the 1992 general elections in Kenya. In one instance, a District Commissioner (DC) ordered National Council of Churches of Kenya (NCCK), an FBO, out of his area of jurisdiction. He stopped it from carrying out development activities and threatened to look for other donors instead of tolerating NCCK and its associated members that included the Bible Society of Kenya, Young Men Christian Association (YMCA), and Young Women Christian Association (YWCA) among others. With this state intervention, the FBOs folded up and closed shop in Baringo district. To the state, FBOs were undermining the legitimacy of the state under the guise of conducting civic education (Owuoche, 2011). The ruling elite saw FBOs as being opposed to the government and therefore out to discredit the "good" name of the government. More importantly is that FBOs were able to mobilize members of parliament to talk about peace and reconciliation; a clear indication of FBOs contribution to democratization in the midst of hostility. Clearly, the main cause of worry for the government was the FBOs' potential to erode the legitimacy of the government with respect to building peace. FBOs were getting into a space monopolized by the government. And the government was losing its basis of support by being seen as incapable of promoting peace. As a way of consolidating its hold on governance, the government found it prudent to paint FBOs as unchristian, unpatriotic and subversive.

During the struggle for multiparty politics, particularly in the 1980s and the 1990s, FBOs were synonymous with defiance to an intolerant political regime (Kenya African Political Union (KANU) - then ruling party) that abhorred any form of criticism. It is FBOs' that came to offer safe sanctuary to almost all the government critics who included both FBO members and non-members. Many a time, fierce government critics such as John Henry Okullu (Bishop of Maseno South), Reverend Timothy Njoya (a Presbyterian Church of East Africa Cleric), Alexander Muge (Eldoret Diocese), Apollo Njonjo and James Orengo (opposition activists), were given a platform by FBOs to present their democratic agenda. FBOs viewed the opposition politicians as an integral part of the "reform movement" hence the organization's support for them. Despite the hostile political environment, the opposition politicians courageously pointed out the government's weaknesses and its inability to nurture the democratic process. This was not only rare but also compromised the individuals' (critics) personal security

FBO leaders were harassed and sometimes beaten in public. FBO leaders who were critical of the regime were left to the fancies and whims of state-sponsored militia gangs like Jeshi La Mzee (Kiswahili for the old man's army) whose financier, though a well known Nairobi-based politician was never brought to book. In this context we mention the 1999 clobbering of the Presbyterian Church of East Africa Cleric, Rev. Timothy Njoya, (a member of the NCCK) in the full view of both national and international mediaand the police, following demonstrations to press for a new constitution. The death of Bishop Alexander Muge of the Eldoret Diocese in a car-crush also raised a lot of questions for the Bishop had received death threats from a Cabinet Minister called Peter Okondo. 
The point is that the state was unable-or unprepared — to insure the safety and rights of certain people, particularly those who did not align themselves with the thinking and actions of the state. The state's refusal to prosecute the perpetrators of violence concealed its own cynical complicity in the aggression towards FBO leaders. Interestingly enough the state's perspective eschewed causation. The state did not give prominence to why FBOs get involved in politics, preferring instead to publicly discredit their activities in the name of political expedience, despite some of the obvious advantages associated with some of the FBOs' activities, particularly in the areas of economic empowerment and peace building.

There are a few cases that may be cited where hostility between FBOs and the State has led to constrained democratization. This is so when reference is made to political reforms that aim at institutionalizing democracy in Kenya, particularly in as far as the search for a new constitutional dispensation is concerned. For example, the promise for a new constitution in Kenya did not conform to the set timetable due to the obvious hostilities between the state on one hand, and the FBOs and other CSOs on the other. Initially, the NARC (National Rainbow Coalition) administration had promised the citizenry that it would deliver a new constitution within the first 100 days of its coming to power that is by April 2003, then it was six months, later one year and then 2007 which was later revised to "post 2007". The delay in the delivery of a new constitution went against NARC's election campaign that it would deliver a new constitution upon ascending into power. Mwai Kibaki as the third President of the Republic of Kenya reaffirmed this position during his inauguration in December 2002 (Kenya Domestic Observation Programme (K-DOP), 2003) [13]. Paradoxically, all actors then agreed on the urgent need for a new constitutional dispensation, but the similarity in their thought system ended there. Each stakeholder seemed to be reading from a different script with the masses suffering the most in terms of failed democratic expectations. This is not to ignore the time spent by Kenyans in 'politicking' at the expense of economic development and the rising ethnic tension due to alignment and realignment in support of certain politicians' positions and balkanization of communities. A lot of political damage had been done by the time Kenya realized its dream of a new constitution on the $27^{\text {th }}$ August 2010 as manifested by the Post Election Violence (PEV) of 2007.

From the above discussion, it is clear that during the Moi regime FBOs-state relation was characterized by hostility. Conflict between FBO and state followed FBOs' open criticism of the government's failure to adhere to democratic principles and procedures in the governance of society. FBOs' open criticism of the state elicited the president's direct criticism. The state viewed the FBO activities as subversive, illegal and unchristian. Civil servants harassed the organization and staff and it is such state interventions that led to FBOs closing shop in some districts. But it is during this time of heightened tension between FBOs and the state that FBOs contributed significantly to the democratization process by being a voice of reason and checking on the excesses of the state. It is within this context of hostile FBO-state relation that we now turn to the Kibaki Era (2002-2013).

\subsection{The President Kibaki Era (2002-2013): Cordial Relations}

Compared to the 1980s, 1990s and 2009 that showed a clear absence of a sustained history of NCCK-state collaboration, 2002-2008 scenario saw a significant shift in the relation between FBOs and the state, from that of open confrontation to that of "co-operative participation". This marked a radical change from the pre-2002 position that was mostly characterized by suspicion and conflict. But again, this "positive rating" created suspicion within a segment of the Kenyan population with the argument being that FBOs and by extension other civil society organizations, were actually pushing a state-agenda. FBOs generally disengaged from active politics and faded into the periphery. Through content analysis of press/newspaper reports, it became clear that FBOs had to a great extent become pro-establishment as opposed to the many years of activism against KANU rule (1980s and the 1990s). Yet the same challenges to the institutionalization of democracy had not been successfully addressed, from the restricted political freedoms, to the issue of transparent governance and ethnic harmony, among others. The avoidance of open confrontation with the ruling political elite could be explained from both the narrow and broad perspectives. From the field survey and secondary data, the study conducted an axiological classification of the factors and arranged them in keeping with their degree of significance for the "absence of FBOs in Political Activism". In adopting this approach, the study divided the factors into the most influential, influential and down to the least influential. The classifications are presented in Table 1.

\subsection{Absence of FBO in Political Activism: Most Influential Factors}

The most influential factors in explaining the absence of FBOs' activism in Kibaki era include co-option of FBO 
Table 1. Factors explaining the absence of FBOs in political activism.

\begin{tabular}{|c|c|}
\hline $\begin{array}{l}\text { Factors Explaining the Absence of FBOs in } \\
\text { Political Activism }\end{array}$ & $\begin{array}{c}\text { Significance for Explaining Absence of FBOs in } \\
\text { Political Activism }\end{array}$ \\
\hline The "Captured" FBOs & Most Influential \\
\hline Short-term objective: Regime Change from "Moi" to "Kibaki” Administration & Most Influential \\
\hline Change of "Guard" & Most Influential \\
\hline Dilemma of Disengagement & Most Influential \\
\hline Strategy Change & Influential \\
\hline Spiritual Matters verses the Political & Influential \\
\hline Absence of “Active-Foot-Soldiers” & Influential \\
\hline FBOs-Church Linkage & Influential \\
\hline Issues of Political Apathy and Disillusionment & Influential \\
\hline Official Recognition of FBOs by the State & Least Influential \\
\hline "Reinterpretation" of Institutionalization of Democracy & Least Influential \\
\hline Contradicting Religious Orders & Least Influential \\
\hline Fragmented FBOs & Least Influential \\
\hline Towards a State-Centered Perspective & Least Influential \\
\hline
\end{tabular}

Source: author's compilation from field and secondary data (2009 and 2013).

activists into government; realization of regime change from authoritarian KANU regime to NARC regime; change of guard, from Moi to Kibaki and dilemma of disengaging from politics.

The absence of FBO activism as alternative agents of political transformation follows "loss" of its leaders, activists and collaborators, to prominent government positions and duties; thus cooperative participation with the state where non-existed before. The co-option greatly weakened their effectiveness in as far as being the rational and alternative voices in the democratization process as was previously the case. A number of leading figures are working for the government for example, Reverend Mutava Musyimi chaired the National Anti-corruption Campaign Steering Committee (NACCSC) until December 2007 when he became the member of parliament for Gachoka; Gichira Kibara, the former Executive Director of National Elections Monitoring Unit (NEMU), an FBO initiative, resigned to take up a senior position in the Ministry of Justice and Constitutional Affairs (Director of Legal Affairs in the Attorney General's Chambers); Kivutha Kibwana, of the National Convention Executive Committee (NCEC), a leading figure during the clamor for a new "people-driven" constitution, became a cabinet minister and currently an advisor to President Kibaki on coalition government matters, another close FBO partner; Martha Koome, formerly of the Federation of Women Lawyers-Kenya Chapter (FIDA) was appointed a Judge of the High Court, to mention but a few. Yet the mentioned among others, were the middle class pro-democracy actors who constantly challenged the state to adhere to democratic principles and procedures in the practice of governance (Owuoche, 2011). More significantly is that the collaboration between state and FBO activists constrained the democratization process due to absence of activists who could challenge the state whenever it undermined basic freedoms and rights and when the state is not accountable to the citizenry. This was not surprising given that:

"It is because of the vested myopia of the political class that the civil society (read FBOs) almost always gets burned when it abandons its traditional role and joins hands with the politicians. It happened in 1997 in the runner-up to the Inter-Parties Parliamentary Group compromise. It happened in 2003 when the government of the National Rainbow Coalition betrayed the reform agenda in spite of its ascendancy to power because of the indispensable support of the civil society. It is happening again today as both the Government and the Opposition gear up to make nice before the elections" (MakauMutua, Sunday Nation, April 15, 2007: 15, in an article "Used and Dumped: That's Civil Society") [14].

The FBOs may have also found it difficult to criticize the actions of the very same people it had worked so 
hard with to "dismantle" the unresponsive and dictatorial KANU regime (1963-2002). With the responsibility of driving the Institutionalization of democracy now firmly in the hands of their former "colleagues-in-arms", the FBOs may have been in a political-operational dilemma. On one hand is how to gain and retain loyalty of their former colleagues and on the other was retaining and winning support of their followers, members and masses.

However, a broader perspective indicates that the FBOs' having achieved their objective, mainly short-term in nature, of regime change and from authoritarianism to a "growing democracy", found it unnecessary to engage in political activism and confrontational politics. In an interview conducted in November 2007 a senior FBO official noted that "The NARC government does not see the Church as an enemy but instead views the Church as a partner in development”. The co-operation between the two was a marked change from confrontations that characterized FBOs-state relation in the 1980s and 1990s. The impetus to FBO activism was change by substitution, as opposed to essential change that would obviously be more beneficial to the democratization process in Kenya.

In relation to the above, since the "desired changes are already with us", the FBOs had stepped aside so as to allow other "actors" (for example other civil society organizations, trade unions, individuals and groups of individuals) to take-over and propel the democratic process to greater heights of success. If this line of argument was to be adopted then the FBOs had become passive observers of change as opposed to the 1990s' period when it was abundantly clear that it was the initiator of change.

It is possible that the FBOs were trapped in a dilemma of disengagement or in other words, have so far failed to develop an effective strategy that synchronizes with the changed political environment. The many years of activism and open confrontation with the government was necessitated by the closed nature of the "Moi regime" (1978-2002). The comparatively "open nature" of the Kibaki regime (explained in terms of increased political freedoms) had brought with it certain challenges that needed time for readjustment on the part of the FBOs.

\subsection{Absence of FBOs in Political Activism: Influencial Factors}

Among the influential factors that explain the absence of FBO activism include: strategy change; dilemma of spiritual matters verses political; absence of active foot soldiers; FBO-Church relations, and issue of political apathy and disillusionment. FBOs may have been forced by the prevailing political environment to retreat and redefine their role in the democratic process and society in general.

FBOs may have been giving more preference to the development of units and structures that can provide opportunities for broader citizen participation in the institutionalization of democracy. FBOs, it is assumed, prefer a closer relationship with the government leading to accrued benefits that range from use of structures of government to carry out civic education; to being in a better position to meet the growing demands of voters. Differently put, the closer working relationship between the two makes it "easier" for FBOs to positively influence the state's democratic agenda unlike when the two are pursuing two different "democratic agendas". According to a then leading FBO activist Rev. Mutava Musyimi (then Secretary General of the National of Churches of Kenya that brought together over thirty eight FBOs), FBOs had indeed made a policy decision to embrace "an institutional approach of principled collaboration" with the government as opposed to "positive criticism" ( $29^{\text {th }}$ March 2007 at 7.52 p.m. on Nation Television, in the program "On the Spot"). The reason behind the policy change was that the NARC government, unlike the KANU government was committed to institutionalization of democracy when certain issues were considered.

An issue worth considering was that after many years of confrontational politics, FBOs were experiencing a lean period with diminished stock of "active-foot-soldiers". Unlike before when we had vocal, confrontational and outspoken FBO leaders who took the political class head-on, this is no longer possible following the retirement, demise or relocation of such leaders. In this group we had the likes of Timothy Njoya and David Gitari who have since retired, Alexander Muge, Henry Okullu, Manasseh Kuria who have been "consumed by the cruel hands of death" and Father Dolan of the Catholic Justice and Peace Commission who had "migrated" to Ireland among others. The fighting spirit represented by such faces having disappeared into the horizon has led to a reality check by the FBOs that it is in their "interest to flow with the political current". Unfortunately, the ruling elite were not keen on institutionalizing democracy (new constitution, effective civic education and increased political freedoms) for it represented a threat to their hold on power.

A driving argument in this article is that the FBOs are but a reflection of the mainstream Church. The changing face of the Church leadership at that time brought with it different priorities. It would therefore be in order to 
argue that unlike some FBO leaders such as David Gitari and Manasseh Kuria who focused on the political due to the then hostile environment, Archbishop Benjamin Nzimbi (then Head of the Anglican Church in Kenya) was more concerned with religious matters, after having taken into consideration the changed political environment that was more tolerant of "political dissent". His leadership was less confrontational. Not forgetting that he rarely appeared in the public domain to comment on political matters. FBOs, with little option and in fear of contradicting its leader/s, thus adopted the same attitude of its superior of "quiet diplomacy and leaving politics to the politicians".

Another probable explanation is that the FBOs, just like the rest of the Kenyan society, were "suffering" from political apathy and disillusionment. The FBOs may have realized that continued participation in the institutionalization of democracy is of "no-much-consequence" in as far as determining policy direction or political change. This has made them to adopt a more cautious, covert and non-participatory approach to politics.

\subsection{Absence of FBOs in Political Activism: Least Influential Factors}

Among the least influential factors explaining the absence of FBOs in political activism include: official recognition by state as an important factor in the democratization process; reinterpretation of institutionalization of democracy; contradicting religious orders; fragmented FBOs, and the re-emergence of the state as the main actor in the democratization process.

There is some probability that at last, the FBOs have received official recognition, thus a change in their political behavior. The state has come to, or been forced to realize that the FBOs are an integral part of the democratization process and that they are closely connected with the national life.

It can also be argued that the FBOs are mainly adapting to the changing political fashions and ideologies, which have gone a long way in influencing the way FBOs' interpret institutionalization of democracy. Their long involvement in institutionalizing democracy may have made them realize that the confrontational approach (FBO-State antagonism) is basically a flawed approach that is no longer fashionable. Antagonisms between the two, at best, lead to the target beneficiaries (the people) losing out in the democratic process.

Further, we argue that the FBOs have sometimes been their own worst enemy when it comes to judging their effectiveness in the institutionalization of democracy in Kenya. Nothing better illustrates this point than the mixed signals they keep sending to both their followers and Kenyans in general. There are times when they come out strongly to defend their position as legitimate contributors to the institutionalization of democracy in Kenya and yet at other times, they contradict this very same position. Many a time the FBO leaders, priests, bishops etc have been quoted in the print media as calling on their colleagues "...not take part in active politics", that includes not accepting positions in state corporations, not being members of the Constituency Development Funds (CDF) and not vie for parliamentary seats. To better illustrate this point, the Kenya Episcopal Conference (an FBO) issued a Pastoral letter in September of 2006 which was categorical in stating that:

\footnotetext{
"As the Vatican Council reminds us, the specific mission of the priests in the Church is not political (our emphasis) economical or social in nature but religious. Nevertheless, priests can and must contribute to setting up a just social order, ...” (Daily Nation, September 23 2006: 4) [15].
}

The above quote captures the dilemma faced by FBOs in as far as their role in institutionalizing democracy is concerned. This leads to a situation where due attention is not given to the political process (institutionalization of democracy) by the FBO leaders in the fear of contradicting the religious order. The FBOs thus operate from a position of weakness in politics and this explains their relative silence in the democratic process particularly in the post-2002 period.

The inability of the FBOs to speak with one voice on the various issues that fall under institutionalization of democracy is another probable explanation to their "quiet nature". This lack of a unified voice has undermined the very source of FBOs' effectiveness in institutionalizing democracy. There have been both intra and interdenominational disagreements between the Anglicans, Catholics and the Muslims on crucial issues such as constitutional reforms, issues of procedure to follow to achieve political reforms and membership of various committees crucial for championing democracy etc.

Among the issues that have led to sharp divisions between the Muslims and Christians is the issue of enshrining the Kadhi Courts in the Constitution. The Christians have always maintained that doing so would elevate the Muslims to a "superior state religion", thus going against the preferred view that the state and religion shall be 
separate and there shall be no state religion, for all are equal. Also, the Ufungamano Initiative that was formed by both the Muslims and the Christians to lead the way in the realization of democratic reforms in Kenya did not remain united for long. Serious divisions emerged leading to the withdrawal of the Muslim FBOs from the Initiative. The differences were never resolved so that the Initiative became identified with Christians while leaving the statistically significant Muslim population, which is estimated at, between 23 - 30 percent of Kenya's population (www.islamonline.net, accessed on August, 16 2013) [16].

In January 2006, The Council of Imams and Preachers of Kenya (CIPK) and the Supreme Council of Kenya Muslims (SUPKEM) rejected calls made by the NCCK that a team consisting of FBO and civil society organizations be handpicked to jump-start the stalled constitutional review talks. The Anglicans (for example the NCCK) were categorical that government in picking the committee members must leave out politicians for they bring with them divisive politics and are driven by self gains. On the other hand, the Muslim FBOs and the Catholic Church were of the view that the success of the constitutional review process was solely dependent on the involvement of all partners. The CIPK and SUPKEM are reported to have said that: "History shows that anybody appointed by the government becomes a puppet and sings to the tune of his bosses. It would be unwise for Kenyans to accept any committee that will be formed either by the President or any other quarters without involving them (CIPK/SUPKEM)" (Daily Nation, January 9, 2006: 3) [17]. Such differences and wrangles between and among the FBOs reflect negatively on their performance on the democratic front and may be used to explain their "silence" on matters of democracy.

The state has of late been largely ignored; and its impact in the democratic process has to a large extent been taken for granted. This is contrary to the earlier periods $\left(17^{\text {th }}\right.$ Century and beyond) when political philosophers were largely preoccupied with the identity of the state, particularly the relations of the state and other non-state actors such as FBOs, the Church, civil society organizations, individuals and other groups. The point is that the state deserves to be taken more seriously as illuminated by its "consequentiality" in institutionalizing democracy. As noted earlier, the state should ideally be in the forefront in the institutionalization of democracy, with other associations playing a complimentary role. If that is not the case, the consequence is usually grave and leads to the derailment of the democratic process.

In relation, the FBOs may have recognized the "right" of the state to regulate the affairs of other associations. This is because the state is the highest authority that can rule. It is in line with this that the state finds it easy to encroach on the spheres of FBOs for example "capturing" their leadership, but the FBOs find it difficult, if not impossible, to do the same to the state. Given the prevailing environment; the FBOs are not autonomous, making it difficult for them to translate their own democratic preferences into authoritative actions.

It should be noted that either one or all of the arguments outlined above, could be used to explain this newfound relationship between the state and FBOs, particularly in the post 2002 period. But it is necessary to pointout that the suggested reasons have not been tested in broad empirical quantitative studies, thus lack empirical explanatory strength. Nevertheless, this cannot prevent us from deducing that in a nascent democracy like Kenya, more politically active FBOs are more beneficial to the institutionalization of democracy than a quiet and noncontroversial FBO.

The "positive relationship" between the two is clearly puzzling given the numerous challenges facing the democratization process in Kenya. In some cases FBOs become preoccupied with the "politics of having a piece of the national cake" thus digressing from their cardinal responsibility of checking and balancing the excesses of the state. This creates a rich germinating ground for "reversal waves" (corruption, insecurity, ethnicity and limited freedoms). The momentous conclusion is that a cordial relationship between FBOs and the state does not automatically nurture the democratic process. In fact it undermines the democratization process for the FBOs' abandon its role of checking on the excesses of the state.

\subsection{The Re-Emergence of the FBOs in 2009}

The preceding section mainly examines FBOs-state relation and its influence on the democratization process. The main argument was that co-operation between FBOs and the state has not been beneficial to the democratization process, for it has led to absence of FBO activism. The FBOs have not been active, as compared to the 1980s and 1990s, in pressurizing the state to embed democratic principles in the practice of governance. The aim of this section is to inquire deeper into the relations between FBOs and state. Specifically to identify the issues that gave rebirth of FBO political activism in the post 2009 period. The FBOs have been more vocal in making 
demands for the government to be more accountable to the citizenry. The demands can be categorized as follows: electoral dispute as a result of the disputed Presidential elections of December 2007; demand to end political impunity; inefficient Grand Coalition Government, and accountability for post elections violence.

The electioneering period leading to the 2007 General Elections saw realignment on the political front. Two major political forces characterized Kenya's political landscape namely the Party of National Unity (PNU) that gravitated around President Mwai Kibaki and the Orange Democratic Movement (ODM) that was the opposing party. PNU consisted of more than ten parties that supported the incumbent, President Mwai Kibaki, re-election. What followed was a closely contested presidential election that led to post election crisis. While the then Electoral Commission of Kenya declared President Kibaki the winner with 4,584,721 votes to Raila's 4,352,993 votes, the "Kriegler Commission" that investigated the conduct of the elections concluded that the winner of the Presidential election could not be determined.

The post-election crisis, following the disputed and discredited presidential election results of December 2007, had far-reaching impact on the institutionalization of democracy in Kenya. It is estimated that 1200 lives were lost; over 300,000 people were internally displaced, over 11,000 people sort refuge in the neighboring countries of Uganda and Tanzania, and property worth more than 90 billion Kenya shillings were destroyed in the violence and demonstrations that followed the disputed results. Despite the troubled political times, FBOs were largely "missing in action" during this period. It was a welcome relief when on the $28^{\text {th }}$ February 2008 , the National Accord and Reconciliation Agreement (NARA) was signed. The NARA was mainly a negotiated agreement between the two principals namely President Mwai Kibaki of Party of National Unity (PNU) and Raila Odinga of the Orange Democratic Movement (ODM), to share power. The signing of the NARA was a step in the right direction in as far as restoring political stability, an important concomitant of institutionalization of democracy, was concerned. Apart from creating an enabling environment of peace, it also committed the parties to carrying out a wide range of reforms that included a comprehensive review of the Constitution within a year from the signing of the power sharing and peace agreement, land reforms and equitable distribution of resources, among others.

The signing of the National Accord did not lead to fast implementation of envisaged reforms. Instead, its implementation awakened ethno-regional rivalry, and increased lack of trust between and among the elite. Institutions remained weak and public confidence in government declined owing to poor delivery of services and general rivalry in governance. Furthermore, the Accord did not lead to coherence and cohesion between the two parties (PNU and ODM). The two principals (the President and the Prime minister) did not speak with one voice on issues of governance and neither do they act decisively against cabinet ministers implicated in official corruption despite overwhelming evidence. The cabinet infighting and the lack of cohesion in decision making by leaders led to an indictment of the country's political leadership. With the FBOs struggling to reclaim their 1980's and 1990's old status as the "vehicle for the reform agenda", it saw the inertia in government as a perfect opportunity to "re-enter" the political scene. The rebirth of FBOs activism can be attributed to the realization by FBOs that religious leaders and the Church had been subsumed into ethno-regional rivalry that also characterized political leadership. The violence may have given impetus to FBOs to be more active in demanding for democratic principles in the practice of governance.

In 2009 FBOs under an umbrella organization, the NCCK, expressed concern on the leadership crisis that was facing the country and that was a recipe for chaos. In a hard-hitting press release, the General Secretary called upon the President and the Prime Minster to take charge so as to save the country from political crisis.

"We are saddened to observe the impression and expression of most Kenyans is that they have a moribund President and an ineffective Prime Minister. In their hearts Kenyans cannot understand how they can be going through an extremely difficult period, with no hope in sight, yet the President, who is constitutionally mandated to give them leadership, is extremely quiet about those issues, almost as if he has lost touch with reality” (Daily Nation, March, $19^{\text {th }}$ 2009: 1) [18].

The FBOs also promised a lot of action while not ruling out "anything in their quest for equality, justice and good governance" (Kenya Television Network (KTN) News at 9.00 p.m.) March 18, 2009: lead news item).

While admitting that they had erred by taking sides during the 2007 elections, the FBOs came out strongly to say that they would not agree to be pushed down any further as to abdicate their role in social reforms The NCCK dismissed the Grand Coalition Government (GCG) as a product of a bungled elections therefore the need for a fresh mandate. 
In summary, the relationship between the state and the FBOs fluctuates between conflict and co-operation depending on the issues at hand, which impact variously on the institutionalization of democracy. More significantly is that the FBOs-State relation is more complex and goes beyond mere correlation. As evident in the 1980s and 1990s periods, there is a strong causal link between a hostile FBOs-State relationship and higher levels of democratic gains in Kenya.

\section{Conclusions}

This article has examined the relation between FBOs and the state, and the consequence of this relation to the democratization process. The discussion has shown that there are obvious contradictions in the relationship between FBOs and the state. At times the relationship is cordial. At other times it is hostile. Factors contributing to cordial relations include: co-option of FBO leaders and activists into government; realization of some gains in the democratization project as manifested by enhanced political freedoms and pursuit of divergent interests with the FBOs focusing more on evangelizing mission. Hostility is as a result of open criticism of the government by FBOs following failure of the government to adhere to democratic principles and procedures in the practice of governance; failure by the government to be accountable to the citizenry; harassment of FBO staff by the political class and civil servants; labeling of FBOs as subversive and unchristian; and alleged interference by FBOs in the arena of the state (politics). From the field survey and literature review, the study found out that the FBOs' contribution to the institutionalization of democracy is the highest when it operates autonomously from the state. It is during such times that FBOs demanded for adherence to the rule of law, new constitutional order, better governance, ethnic harmony and competitive political environment, and provided a platform for critics of the government to operate from. The colonial, immediate post colonial (1960 and 1970s) and Kibaki Era (2002-2013) regimes indicate a "captured" FBO whose contribution to the democratization process is dismal and below the expected. The argument being that whenever there is a fusion as a consequence of the influential tentacles of the state, it is institutionalization of democracy that suffers.

The incorporation of the FBO leaders into government has no doubt, making them more accommodating to the interest of the ruling elite that is not always beneficial to the democratization process. It is this "unholy" alliance that has led to public criticism that touches on the honesty, sincerity and ability of the FBOs to nurture and sustain institutionalization of democracy in Kenya. The events of the 1980's, 1990's and 2009 clearly show that FBOs need to operate as an independent player if they are to remain relevant in the democratization process. The article therefore demonstrated that a cordial relationship between FBOs and the state does not necessarily enhance FBOs' effectiveness in the institutionalization of democracy in Kenya.

\section{References}

[1] Kanyinga, K. (2015) Evolution of Kenya’s Civil Society. Sunday Nation, 1 March 2015.

[2] Hegel, F. (1988) Introduction to the Philosophy of History: With an Appendix from the Philosophy of Rights. Hachett Pub. Co. Inc., New York.

[3] Owuoche, S. (2011) Faith Based Organizations and the Institutionalization of Democracy in Kenya: A Case Study of the National Council of Churches of Kenya. Unpublished PhD Thesis, Nairobi.

[4] Keane, J. (1988) Democracy and Civil Society. Verso, London.

[5] Owuoche, S. (2010) The Church in the Struggle for Democracy in Kenya. Mvule Africa Publishers, Nairobi.

[6] Diamonds, L. (1999) Developing Democracy: Towards Consolidation. John Hopkins University Press, Baltimore.

[7] Filali-Ansary, A. (2003) Muslims and Democracy. In: Diamonds, L., Plattner, M.F. and Brumberg, D., Eds., Islam and Democracy in the Middle East, The John Hopkins University Press, Baltimore, 28-46.

[8] Huntington, S. (1984) Will More Countries be Democratic? Political Science Quarterly, 99, 193-218. http://dx.doi.org/10.2307/2150402

[9] Throup, D. and Hornsby, C. (1995) Multiparty Politics in Kenya: The Kenyatta and Moi States and the Thriumph of the System in the 1992 Election. James Currey, Oxford.

[10] Mamdani, M. (1995) A Critique of the State and Civil Society Paradigm in Africanist Studies. In: Mamdani, M. and Wamba-dia-Wamba, E., Eds., African Studies in Social Movements and Democracy, Codesria, Oxford, 602-616.

[11] Machiavelli, N. (1952) The Prince. Mentor Books, New York.

[12] Sibley, M. (1996) Political Ideas and Ideologies: A History of Political Thought. Surjeet Publishers, Delhi. 
[13] Kenya Elections Domestic Observation Forum (2008) The Kenya Elections 2007: Losses, Gains and Lessons. KEDOF, Nairobi.

[14] Sunday Nation (2007) “Used and Dumped: That’s Civil Society”, by Makau Mutua. Sunday Nation, 15 April 2007.

[15] Daily Nation (2006) “The Church Speaks” by Nation Reporter. Daily Nation, 23 September 2006.

[16] The Muslim Minority Huge Challenges by Abdulkarim Mohamed Jimale, Freelance Journalist, Kenya. www.onislam.net/english/politics/africa/427664.html

[17] Daily Nation (2006) “CIPK/ SUPKEM Reacts” by Nation Reporter. Daily Nation, 9 January 2006.

[18] Daily Nation (2009) Press Release Advertisement. Daily Nation, 19 March 2009. 